\title{
Induction of DNA damage by deguelin is mediated through reducing DNA repair genes in human non-small cell lung cancer NCI-H460 cells
}

\author{
BIN-CHUAN JI ${ }^{1 *}$, CHIEN-CHIH YU ${ }^{2 *}$, SU-TSO YANG ${ }^{3,4}$, TE-CHUN HSIA ${ }^{5}$, JAI-SING YANG ${ }^{6}$, \\ KUANG-CHI LAI ${ }^{7,8}$, YANG-CHING KO ${ }^{9}$, JEN-JYH LIN ${ }^{10,11}$, TUNG-YUAN LAI ${ }^{12,13}$ and JING-GUNG CHUNG ${ }^{14,15}$ \\ ${ }^{1}$ Division of Chest Medicine, Department of Internal Medicine, Changhua Christian Hospital, Changhua 500; \\ Schools of ${ }^{2}$ Pharmacy and ${ }^{3}$ Chinese Medicine, China Medical University, Taichung 404; Departments of \\ ${ }^{4}$ Radiology and ${ }^{5}$ Internal Medicine, China Medical University Hospital, Taichung 404; ${ }^{6}$ Department of \\ Pharmacology, China Medical University, Taichung 404; ${ }^{7}$ Department of Surgery, China Medical University \\ Beigang Hospital, Yunlin 651; ${ }^{8}$ School of Medicine, China Medical University, Taichung 404; ${ }^{9}$ Division of \\ Pulmonary and Critical Care Medicine, Department of Internal Medicine, St. Martin De Porres Hospital, Chiayi 600; \\ ${ }^{10}$ Graduate Institute of Chinese Medicine, China Medical University, Taichung 404; ${ }^{11}$ Division of Cardiology, \\ Department of Medicine, China Medical University Hospital, Taichung 404; ${ }^{12}$ Department of Chinese Medicine, \\ Wan Fang Hospital, Taipei Medical University, Taipei 116; ${ }^{13}$ Graduate Institute of Pharmacognosy, College \\ of Pharmacy, Taipei Medical University, Taipei 110; ${ }^{14}$ Department of Biological Science and Technology, China \\ Medical University, Taichung 404; ${ }^{15}$ Department of Biotechnology, Asia University, Taichung 413, Taiwan, R.O.C.
}

Received August 30, 2011; Accepted November 3, 2011

DOI: $10.3892 /$ or.2012.1622

\begin{abstract}
It has been shown that deguelin, one of the compounds of rotenoids from flavonoid family, induced cytotoxic effects through induction of cell cycle arrest and apoptosis in many types of human cancer cell lines, but deguelin-affected DNA damage and repair gene expression (mRNA) are not clarified yet. We investigated the effects of deguelin on DNA damage and associated gene expression in human lung cancer NCI-H460 cells in vitro. DNA damage was assayed by using the comet assay and DNA gel electrophoresis and the results indicated that NCI-H460 cells treated with 0 , 50,250 and $500 \mathrm{nM}$ deguelin led to a longer DNA migration smear based on the single cell electrophoresis and DNA fragmentation occurred based on the examination of DNA
\end{abstract}

Correspondence to: Dr Jing-Gung Chung, Department of Biological Science and Technology, China Medical University, 91 HsuehShih Road, Taichung 404, Taiwan, R.O.C.

E-mail: jgchung@mail.cmu.edu.tw

Dr Tung-Yuan Lai, Department of Chinese Medicine, Wan Fang Hospital, Taipei Medical University, Taipei 116, Taiwan, R.O.C.

E-mail: 100322@w.tmu.edu.tw

${ }^{*}$ Contributed equally

Key words: deguelin, DNA damage, comet assay, DNA repair, human lung cancer NCI-H460 cells gel electrophoresis. DNA damage and repair gene expression (mRNA) were evaluated by using real-time PCR assay and the results indicated that 50 and $250 \mathrm{nM}$ deguelin for a 24-h exposure in NCI-H460 cells, decreased the gene levels of breast cancer 1, early onset (BRCA1), DNA-dependent serine/ threonine protein kinase $(D N A-P K), O^{6}$-methylguanine-DNA methyltransferase $(M G M T), \mathrm{p} 53$, ataxia telangiectasia mutated (ATM) and ataxia-telangiectasia and Rad3-related (ATR) mRNA expressions. Collectively, the present study showed that deguelin caused DNA damage and inhibited DNA damage and repair gene expressions, which might be due to deguelin-inhibited cell growth in vitro.

\section{Introduction}

Deguelin, one of the most critical rotenoids from the flavonoid family, derived from the natural plants in the Mundulea sericea family, has been shown to be effective as a chemopreventive and therapeutic agent against different cancer cells such as tumors of the colon, lung and breast (1-3). The functions of human cancer cell lines through the induction of cell cycle arrest and apoptosis can be downregulated for specific cell survival proteins, including Akt and mitogen-activated protein kinase (MAPK) (4-6). Furthermore, deguelin inhibited the transcriptional regulation of ornithine decarboxylase (7), NF- $\kappa \mathrm{B}$ gene expression $(8,9)$ and hypoxia-inducible factor- $1 \alpha(\mathrm{HIF}-1 \alpha)(10)$.

DNA damage is associated with diseases such as neurodegeneration in age-related disease, cerebral ischemia and brain trauma (11). Thus, agent-induced DNA damage may lead to cell mutation and then cause malignancy $(12,13)$. To fully 
understand the actions of anticancer drugs is critical and can offer more information regarding the anticancer drug-induced side effects in patients.

Although substantial evidence has shown that deguelin induced cell death of human cancer cell lines, there is no information to address the effects of deguelin-provoked DNA damage in human lung cancer cells. The purpose of the present study was to investigate the effects of deguelin on DNA damage and DNA repair associated gene expression (mRNA) in human lung cancer NCI-H460 cells. Our results revealed that deguelin induced DNA damage and inhibited DNA associated gene expression in NCI-H460 cells in vitro.

\section{Materials and methods}

Chemicals and reagents. Deguelin, dimethyl sulfoxide (DMSO), propidium iodide (PI), Tris- $\mathrm{HCl}$ and Triton X-100 was obtained from Sigma-Aldrich Corp. (St. Louis, MO, USA). RPMI-1640 medium, fetal bovine serum (FBS), L-glutamine, penicillin-streptomycin and trypsin-EDTA were obtained from Gibco Life Technologies (Grand Island, NY, USA).

Cell culture. The human lung cell line (NCI-H460) was purchased from the Food Industry Research and Development Institute (Hsinchu, Taiwan) and maintained at $37^{\circ} \mathrm{C}$ with $5 \%$ $\mathrm{CO}_{2}$ and $95 \%$ air in RPMI-1640 medium supplemented with $10 \%$ FBS, 2 mM L-glutamine, 100 units/ml penicillin and $100 \mu \mathrm{g} / \mathrm{ml}$ streptomycin. The medium was changed every 2 days (14). Deguelin was dissolved in DMSO and added directly to cell culture medium at a final concentration of $0.5 \%$ DMSO. This concentration had no effect on cell growth or other assays.

PI exclusion method and flow cytometric assay. Approximately $2 \times 10^{5}$ cells/well of NCI-H640 cells in 12-well plates were incubated with deguelin at final concentrations of 0 (vehicle, $0.5 \%$ DMSO), 50, 250 and $500 \mathrm{nM}$ and for $24 \mathrm{~h}$, or the cells were treated with $250 \mathrm{nM}$ deguelin for 0,24,48 and $72 \mathrm{~h}$. Cells from each treatment were stained with PI $(5 \mu \mathrm{g} / \mathrm{ml})$ and analyzed by flow cytometry (Becton-Dickinson, San Jose, CA, USA) and cell viability was calculated as previously described $(15,16)$.

Comet assay. NCI-H460 cells at a density of $2 \times 10^{5}$ cells/well in 12-well plates were incubated with 0 (vehicle, $0.5 \%$ DMSO), 50,250 and $500 \mathrm{nM}$ degulein and $5 \mu \mathrm{M}$ hydrogen peroxide $\left(\mathrm{H}_{2} \mathrm{O}_{2}\right.$, positive control) for $48 \mathrm{~h}$ in RPMI-1640 medium grown at $37^{\circ} \mathrm{C}$ in $5 \% \mathrm{CO}_{2}$ and $95 \%$ air. Cells were harvested for the examination of DNA damage using the comet assay as previously described $(17,18)$. Comet tail length was calculated and quantified using the TriTek CometScore ${ }^{\mathrm{TM}}$ software image analysis system (TriTek Corp., Sumerduck, VA, USA) as previously described (18).

DNA gel electrophoresis. NCI-H460 cells ( $1 \times 10^{6}$ cells/well) seeded in 6-well plates were incubated with degulein at final concentrations of 0 (vehicle, 0.5\% DMSO), 50, 250 and $500 \mathrm{nM}$ for $48 \mathrm{~h}$. Cells from each treatment were individually isolated by using DNA isolation kit (Genemark Technology Co., Ltd., Tainan, Taiwan) (19). The DNA electrophoresis was carried out in $1.5 \%$ agarose gel in Tris-borate EDTA (TBE)
Table I. Primer sequences used for real-time PCR.

\begin{tabular}{ll}
\hline Primer name & \multicolumn{1}{c}{ Primer sequence } \\
\hline BRCA1 & F: CCAGGGAGTTGGTCTGAGTGA \\
& R: ACTTCCGTAAGGCATCGTAACAC \\
DNA-PK & F: CCAGCTCTCACGCTCTGATATG \\
& R: CAAACGCATGCCCAAAGTC \\
MGMT & F: CCTGGCTGAATGCCTATTTCC \\
& R: TGTCTGGTGAACGACTCTTGCT \\
p53 & F: GGGTTAGTTTACAATCAGCCACATT \\
& R: GGGCCTTGAAGTTAGAGAAAATTCA \\
ATM & F: TTTACCTAACTGTGAGCTGTCTCCAT \\
& R: ACTTCCGTAAGGCATCGTAACAC \\
ATR & F: GGGAATCACGACTCGCTGAA \\
& R: CTAGTAGCATAGCTCGACCATGGA \\
GAPDH & F: ACACCCACTCCTCCACCTTT \\
& R: TAGCCAAATTCGTTGTCATACC \\
\hline
\end{tabular}

The human DNA sequences were evaluated using the Primer Express software and each assay was run on an Applied Biosystems 7300 real-time PCR system. Each assay was conducted at least trice to ensure reproducibility. BRCA1, breast cancer gene 1; DNAPK, DNA-dependent serine/threonine protein kinase; MGMT, $O^{6}$-methylguanine-DNA methyltransferase; ATM, ataxia telangiectasia mutated; ATR, ataxia-telangiectasia and Rad3-related; GAPDH, glyceraldehydes-3-phosphate dehydrogenase.

buffer (Amresco, Solon, OH, USA) at $15 \mathrm{~V}$ for $2 \mathrm{~h}$. DNA was stained with ethidium bromide (EtBr, Sigma-Aldrich Corp.), then examined and photographed by fluorescence microscope as previously described $(20,21)$.

Real-time PCR analysis. Approximately $1 \times 10^{6}$ cells/well of NCI-H460 cells in 6-well plates were incubated with or without 0,50 and $250 \mathrm{nM}$ degulein for a 24-h treatment in RPMI-1640 medium grown at $37^{\circ} \mathrm{C}$ in $5 \% \mathrm{CO}_{2}$ and $95 \%$ air. The total RNA from each treatment was extracted by using the Qiagen RNeasy Mini Kit (Qiagen, Inc., Valencia, CA, USA) as previously described $(14,22)$. Briefly, RNA samples were reverse-transcribed for $30 \mathrm{~min}$ at $42^{\circ} \mathrm{C}$ with High Capacity cDNA Reverse Transcription Kit according to the standard protocol of the supplier (Applied Biosystems, Carlsbad, CA, USA). For quantitative PCR from each sample that was performed in the conditions: $2 \mathrm{~min}$ at $50^{\circ} \mathrm{C}, 10 \mathrm{~min}$ at $95^{\circ} \mathrm{C}$, and 40 cycles of $15 \mathrm{sec}$ at $95^{\circ} \mathrm{C}, 1 \mathrm{~min}$ at $60^{\circ} \mathrm{C}$ using $1 \mu \mathrm{l}$ of the cDNA reverse-transcribed as described above, $2 \mathrm{X}$ SYBRGreen PCR Master Mix (Applied Biosystems) and $200 \mathrm{nM}$ of forward and reverse primers as shown in Table I. Finally, each assay was run on an Applied Biosystems 7300 real-time PCR system in triplicates and expression fold-change was derived using the comparative $\mathrm{C}_{\mathrm{T}}$ method $(15,18)$.

Statistical analysis. The data are presented as the mean \pm SD and Student's $t$-test was used to analyze differences between 
A

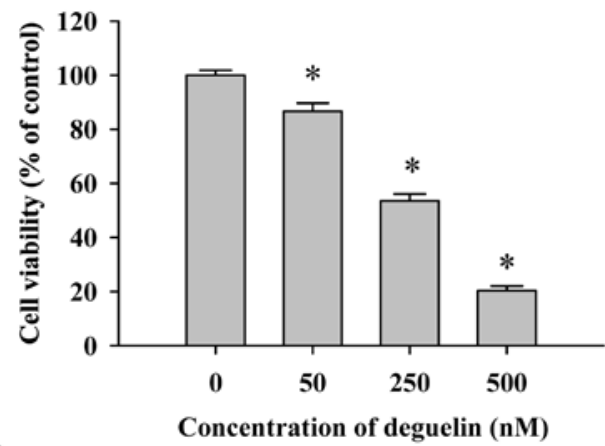

B

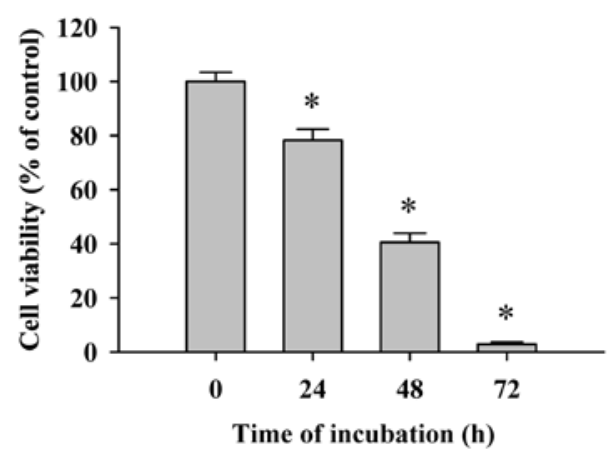

Figure 1. Deguelin decreased the percentage of viable human lung cancer NCI-H460 cells. Cells at a density of $2 \times 10^{5}$ cells/well were placed in 12 -well plates and incubated with deguelin at final concentrations of 0 (vehicle, $0.5 \%$ DMSO), 50,250 and $500 \mathrm{nM}$ for $48 \mathrm{~h}$ (A), or cells were treated with $250 \mathrm{nM}$ deguelin for $0,24,48$ and $72 \mathrm{~h}$ (B). Cells from each treatment were stained with PI $(5 \mu \mathrm{g} / \mathrm{ml})$ and analyzed by flow cytometry as described in Materials and methods. ${ }^{*}$ p $<0.05$ was considered significant when compared with vehicle control cells $(0 \mu \mathrm{M})$.

deguelin-treated and untreated (control) groups. All the statistical analyses were performed, and $\mathrm{p}<0.05$ was considered statistically significant.

\section{Results}

Flow cytometric assay for the effects of deguelin on the percentage of viable NCI-H460 cells. Cells were treated with various concentrations $(0,50,250$ and $500 \mathrm{nM})$ of deguelin for $48 \mathrm{~h}$ or were treated with $250 \mathrm{nM}$ of deguelin for 0,24 , 48 and $72 \mathrm{~h}$. The cells from each treatment were collected for the measurement of percentage of viable NCI-H460 cells. The results shown in Fig. 1 indicate that deguelin decreased the cell viability and these effects are dose- and time-dependent (Fig. 1).

Comet assay for the effects of deguelin-triggered DNA damage in NCI-H460 cells. We investigated that deguelin-induced DNA damage of NCI-H460 cells in vitro. The comet assay was selected for determining DNA damage and the results are shown in Fig. 2, indicating that deguelin provoked DNA damage in NCI-H460 cells in a dose-dependent manner. The higher concentration of deguelin led to a longer DNA migration smear (comet tail). It is well documented that $\mathrm{H}_{2} \mathrm{O}_{2}$ is a highly reactive oxygen species and it has been used as positive control for numerous studies $(23,24)$. The results from present studies
A

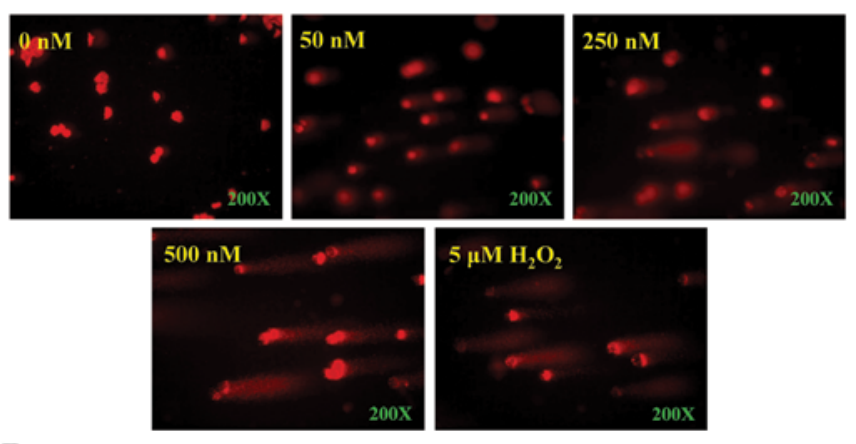

B

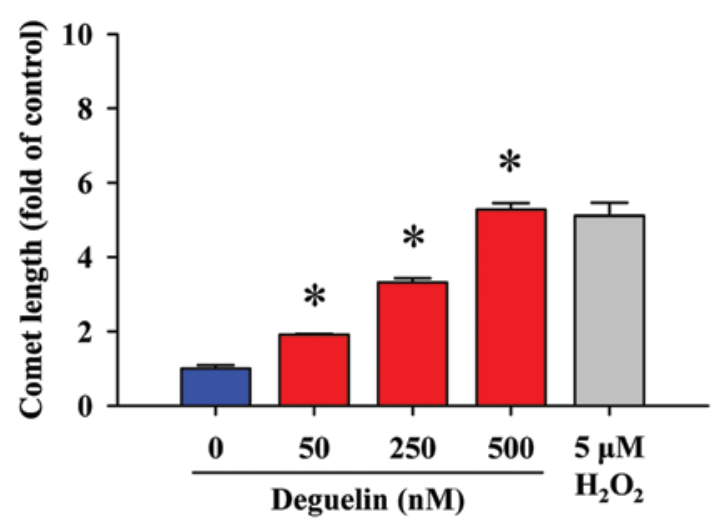

Figure 2. Deguelin induced DNA damage in NCI-H460 cells as determined by comet assay. Cells at a density of $2 \times 10^{5}$ cells/well in 12 -well plates were exposed to deguelin at final concentrations of $0,50,250$ and $500 \mathrm{nM}$, and $5 \mu \mathrm{M} \mathrm{H}_{2} \mathrm{O}_{2}$ (positive control) for $48 \mathrm{~h}$ and DNA damage was determined by comet assay as described in Materials and methods. (A) Representative picture of comet assay for dose-dependent effects; (B) comet length (fold of control) was quantified using the TriTek CometScore software image analysis system. ${ }^{*} \mathrm{p}<0.05$ was considered significant when compared with vehicle control cells $(0 \mu \mathrm{M})$.

indicated that $5 \mu \mathrm{M} \mathrm{H}_{2} \mathrm{O}_{2}$-induced comet tail occurred and was used as a positive control.

DNA gel electrophoresis for the effects of deguelin-induced DNA damage and fragmentation in NCI-H460 cells. In comet assay, we found that deguelin induced DNA damage in NCI-H460 cells. Thus, DNA gel electrophoresis was used to investigate whether or not deguelin causes DNA fragmentation in NCI-H460 cells. Thus, DNA was isolated from NCI-H460 cells after treatment with deguelin for $48 \mathrm{~h}$ and then DNA fragments were determined by DNA gel electrophoresis. The results showed that deguelin induced DNA damage and fragments in NCBI-H460 cells in a dose- and time-dependent manner (Fig. 3). The highest dose of deguelin (500 $\mathrm{nM})$ incubation of NCI-H460 cells led to more DNA damage and fragments than that of low dose $(50 \mathrm{nM})$ deguelin incubation.

Real-time PCR for examining the effects of deguelin on DNA damage and repair gene expression in NCI-H460 cells. Based on the above results, deguelin induced DNA damage and fragments in NCI-H460 cells. We further investigated the effects of deguelin on gene expression of DNA damage and repair in NCI-H460 cells. We also used DNA agarose gel electrophoresis for examining the products (Fig. 3). The real-time PCR 


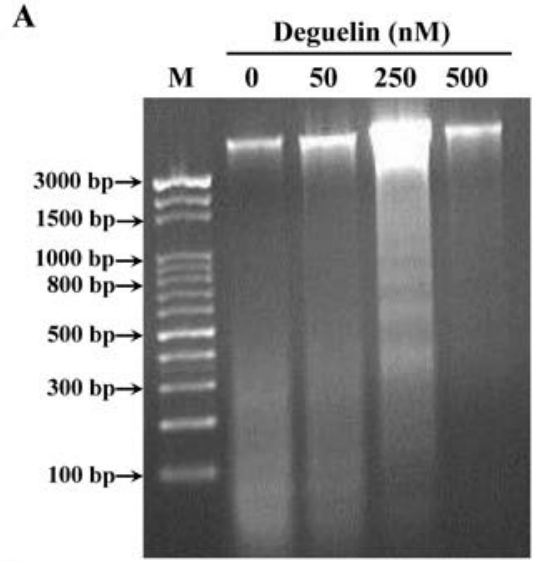

B

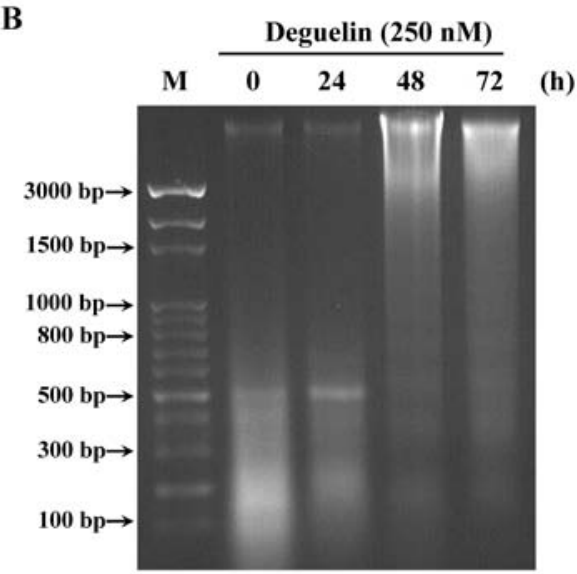

Figure 3. Deguelin-induced DNA damage in NCI-H460 cells was determined by agrose DNA gel electrophoresis. Cells at a density of $1 \times 10^{6}$ cells/well were placed in 6-well plates were incubated with deguelin at final concentrations of $0,50,250$ and $500 \mathrm{nM}$ for $48 \mathrm{~h}$. Cells were collected and DNA were isolated from each treatment for gel electrophoresis described in Materials and methods. M, marker.

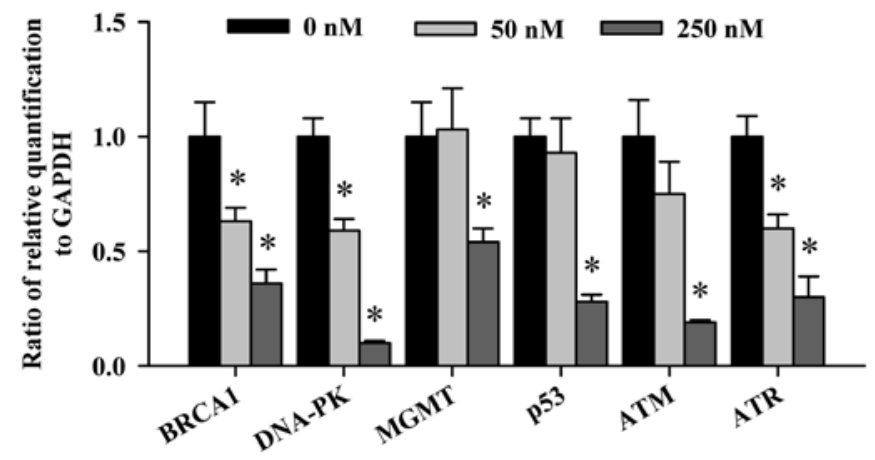

Figure 4. Deguelin-inhibited DNA damage and repair gene expression in NCI-H640 cells were determined by real-time PCR. Total RNA was extracted from the NCI-H640 cells after treatment with 0,50 and $250 \mathrm{nM}$ deguelin for $24 \mathrm{~h}$, and RNA samples were reverse-transcribed for real-time PCR as described in Materials and methods. The ratios of BRCA1, DNA-PK, MGMT, p53, ATM and ATR mRNA/GAPDH are shown and data represent the mean \pm SD of three experiments. ${ }^{*} p<0.05$ was considered significant.

results are shown in Fig. 5 and indicate that all the examined gene expressions associated with DNA damage and repair such as the BRCA1, DNA-PK, MGMT, p53, ATM and ATR mRNA were decreased (Fig. 4) in NCI-H460 cells after a 24-h

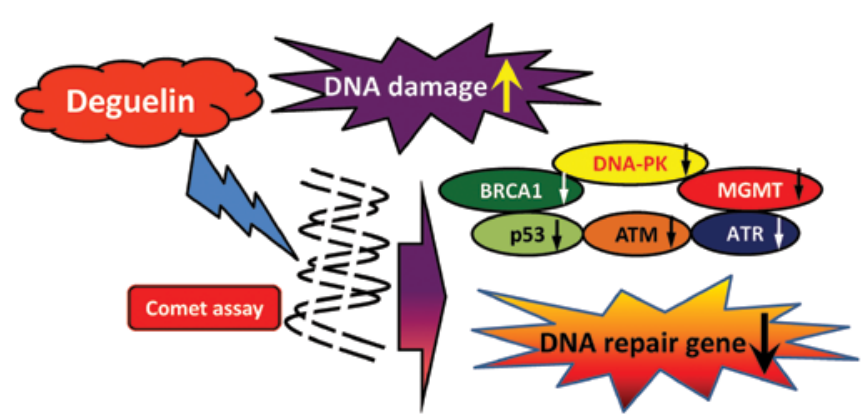

Figure 5. The possible flow chart for deguelin-inhibited gene expression of DNA damage and repair in human lung cancer NCI-H460 cells.

treatment of deguelin. Especially, the gene levels of $B R C A 1$, $D N A-P K, A T M$ and $A T R$ expression were inhibited dosedependently in NCI-H460 cells. However, the gene levels of $M G M T$ and $p 53$ mRNA expression were decreased in NCI-H460 cells only at high dose of deguelin exposure.

\section{Discussion}

Several reports have demonstrated that deguelin can induce cytotoxic effects and induce apoptosis in many human cancer cell lines $(1,4,26-28)$. However, there is no report addressing deguelin-induced DNA damage in human lung cancer cells. In the present study, a dose-dependent increase in DNA damage (Fig. 2) was observed in human lung cancer NCI-H460 cells associated with a loss of cell viability in a dose- and timedependent manner (Fig. 1). These findings indicated: i) DNA damage from comet assay (single cell gel electrophoresis) occured in the tail moment of the comets from NCI-H460 cells, the longer the comet tail the higher the DNA damage (Fig. 2) in a dose-dependent manner; ii) DNA fragments from DNA gel electrophoresis indicated that high dose of deguelin treatment led to high fragmentation in NCI-H460 cells (Fig. 3).

Comet assay is a highly sensitive technique for DNA damage examination and thus it has been used for screening the effects of agent on DNA damage in cells (28-30). Furthermore, a measurement for trend-break formation during the process of excision repair of DNA could be used $(31,32)$. In our earlier studies, we have shown that deguelin induced apoptosis in human cancer cell lines (data not shown), but we also found that deguelin induced apoptosis based on DNA fragmentation occur in NCI-H460 cells after exposure to deguelin from DNA agarose gel electrophoresis assay (Fig. 3). Our earlier studies also showed that deguelin-induced apoptosis may be through the production of reactive oxygen species (ROS) in NCI-H460 cells (data not shown); thus, we suggest that deguelin induced DNA damage may be via the production of ROS. Further studies are needed to establish the role of the interaction of deguelin with DNA in cancer cells.

Numerous evidence has shown that in cells, agents can induce DNA damage which can be reduced by DNA repair system through eliminating DNA lesions (33-35). In the present study, our results from the comet assay (Fig. 2) and DNA gel electrophoresis indicated that deguelin-induced 
DNA damage (Fig. 3) in NCI-H460 cells. Furthermore, results were obtained from real-time PCR (Fig. 4) which indicated that DNA repair gene expression including $B R C A 1$, $D N A-P K, M G M T, p 53, A T M$ and $A T R$ were inhibited in deguelin-treated NCI-H460 cells. Importantly, the gene levels of BRCA1, DNA-PK, ATM, ATR and DNA-PK expressions were reduced dose-dependently.

Cells after stimulation by agents cause DNA damage and the DNA damage checkpoints are signal transduction pathways which are involved in the cell cycle and cellular responses to DNA damage in order to maintain genomic integrity (36-38). Especially, the ATM and ATR are two master checkpoint kinases activated by double-stranded DNA breaks (DSBs) (39). In UV-damaged DNA and incompletely replicated DNA, the ATR kinase is responsible for initiating the DNA damage checkpoint (40). BRCA1 (tumor suppressor) plays critical roles in DNA repair, cell cycle checkpoint control and maintenance of genomic stability in human breast and ovarian cancer (41). Moreover, DNA-PK plays a critical role in DNA damage repair (42). MGMT reduces cytotoxicity of therapeutic or environmental alkylating agents (43).

In conclusion, the possible flow charts for deguelin-affected DNA damage in human lung cancer NCI-H460 cells are summarized in Fig. 5 which indicates that deguelin induced DNA damage followed by the inhibition of DNA repair associated gene expressions (mRNA) including BRCA1, DNA-PK, MGMT, p53, ATM and ATR, resulting in maintenance of DNA damage (Fig. 5).

\section{Acknowledgements}

This study was supported by grant 99-CCH-IRP-08 from the Changhua Christian Hospital, Changhua, Taiwan.

\section{References}

1. Murillo G, Salti GI, Kosmeder JW II, Pezzuto JM and Mehta RG: Deguelin inhibits the growth of colon cancer cells through the induction of apoptosis and cell cycle arrest. Eur J Cancer 38: 2446-2454, 2002.

2. Lee HY, Oh SH, Woo JK, et al: Chemopreventive effects of deguelin, a novel Akt inhibitor, on tobacco-induced lung tumorigenesis. J Natl Cancer Inst 97: 1695-1699, 2005.

3. Murillo-Godinez G: The flugge's drops. Rev Med Inst Mex Seguro Soc 47: 290, 2009.

4. Lee JH, Lee DH, Lee HS, Choi JS, Kim KW and Hong SS: Deguelin inhibits human hepatocellular carcinoma by antiangiogenesis and apoptosis. Oncol Rep 20: 129-134, 2008.

5. Chun KH, Kosmeder JW II, Sun S, et al: Effects of deguelin on the phosphatidylinositol 3-kinase/Akt pathway and apoptosis in premalignant human bronchial epithelial cells. J Natl Cancer Inst 95: 291-302, 2003.

6. Lee HY: Molecular mechanisms of deguelin-induced apoptosis in transformed human bronchial epithelial cells. Biochem Pharmacol 68: 1119-1124, 2004.

7. Gerhauser C, Mar W, Lee SK, et al: Rotenoids mediate potent cancer chemopreventive activity through transcriptional regulation of ornithine decarboxylase. Nat Med 1: 260-266, 1995.

8. Nair AS, Shishodia S, Ahn KS, Kunnumakkara AB, Sethi G and Aggarwal BB: Deguelin, an AKT inhibitor, suppresses IkappaBalpha kinase activation leading to suppression of NF-kappaB-regulated gene expression, potentiation of apoptosis, and inhibition of cellular invasion. J Immunol 177: 5612-5622, 2006.

9. Dell'Eva R, Ambrosini C, Minghelli S, Noonan DM, Albini A and Ferrari N: The Akt inhibitor deguelin, is an angiopreventive agent also acting on the NF-kappaB pathway. Carcinogenesis 28: 404-413, 2007.
10. Oh SH, Woo JK, Jin Q, et al: Identification of novel antiangiogenic anticancer activities of deguelin targeting hypoxia-inducible factor-1 alpha. Int J Cancer 122: 5-14, 2008.

11. Maier CM and Chan PH: Role of superoxide dismutases in oxidative damage and neurodegenerative disorders. Neuroscientist 8: 323-334, 2002.

12. Paz-Elizur T, Sevilya Z, Leitner-Dagan Y, Elinger D, Roisman LC and Livneh Z: DNA repair of oxidative DNA damage in human carcinogenesis: potential application for cancer risk assessment and prevention. Cancer Lett 266: 60-72, 2008.

13. Lavelle C, Salles B and Wiesmuller L: DNA repair, damage signaling and carcinogenesis. DNA Repair (Amst) 7: 670-680, 2008.

14. Ji BC, Hsu WH, Yang JS, et al: Gallic acid induces apoptosis via caspase-3 and mitochondrion-dependent pathways in vitro and suppresses lung xenograft tumor growth in vivo. J Agric Food Chem 57: 7596-7604, 2009.

15. Lu CC, Yang JS, Huang AC, et al: Chrysophanol induces necrosis through the production of ROS and alteration of ATP levels in J5 human liver cancer cells. Mol Nutr Food Res 54: 967-976, 2010.

16. Liu KC, Huang AC, Wu PP, et al: Gallic acid suppresses the migration and invasion of PC-3 human prostate cancer cells via inhibition of matrix metalloproteinase-2 and -9 signaling pathways. Oncol Rep 26: 177-184, 2011.

17. Yu FS, Yang JS, Yu CS, et al: Safrole induces apoptosis in human oral cancer HSC-3 cells. J Dent Res 90: 168-174, 2011.

18. Chiang JH, Yang JS, Ma CY, et al: Danthron, an anthraquinone derivative, induces DNA damage and caspase cascades-mediated apoptosis in SNU-1 human gastric cancer cells through mitochondrial permeability transition pores and Bax-triggered pathways. Chem Res Toxicol 24: 20-29, 2011.

19. Kuo CL, Wu SY, Ip SW, et al: Apoptotic death in curcumintreated NPC-TW 076 human nasopharyngeal carcinoma cells is mediated through the ROS, mitochondrial depolarization and caspase-3-dependent signaling responses. Int J Oncol 39: 319-328, 2011.

20. Chen HY, Lu HF, Yang JS, et al: The novel quinolone CHM-1 induces DNA damage and inhibits DNA repair gene expressions in a human osterogenic sarcoma cell line. Anticancer Res 30: 4187-4192, 2010.

21. Yang JS, Chen GW, Hsia TC, et al: Diallyl disulfide induces apoptosis in human colon cancer cell line (COLO 205) through the induction of reactive oxygen species, endoplasmic reticulum stress, caspases casade and mitochondrial-dependent pathways. Food Chem Toxicol 47: 171-179, 2009.

22. Ho YT, Yang JS, Li TC, et al: Berberine suppresses in vitro migration and invasion of human SCC- 4 tongue squamous cancer cells through the inhibitions of FAK, IKK, NF-kappaB, u-PA and MMP-2 and -9. Cancer Lett 279: 155-162, 2009.

23. Riviere J, Ravanat JL and Wagner JR: Ascorbate and $\mathrm{H}_{2} \mathrm{O}_{2}$ induced oxidative DNA damage in jurkat cells. Free Radic Biol Med 40: 2071-2079, 2006.

24. Visvardis EE, Tassiou AM and Piperakis SM: Study of DNA damage induction and repair capacity of fresh and cryopreserved lymphocytes exposed to $\mathrm{H} 2 \mathrm{O} 2$ and gamma-irradiation with the alkaline comet assay. Mutat Res 383: 71-80, 1997.

25. Lee H, Lee JH, Jung KH and Hong SS: Deguelin promotes apoptosis and inhibits angiogenesis of gastric cancer. Oncol Rep 24: 957-963, 2010.

26. Peng XH, Karna P, O'Regan RM, et al: Down-regulation of inhibitor of apoptosis proteins by deguelin selectively induces apoptosis in breast cancer cells. Mol Pharmacol 71: 101-111, 2007.

27. Hail N Jr and Lotan R: Apoptosis induction by the natural product cancer chemopreventive agent deguelin is mediated through the inhibition of mitochondrial bioenergetics. Apoptosis 9: 437-447, 2004.

28. Pool-Zobel BL, Lotzmann N, Knoll M, et al: Detection of genotoxic effects in human gastric and nasal mucosa cells isolated from biopsy samples. Environ Mol Mutagen 24: 23-45, 1994.

29. Donatus IA, Sardjoko and Vermeulen NP: Cytotoxic and cytoprotective activities of curcumin. Effects on paracetamol-induced cytotoxicity, lipid peroxidation and glutathione depletion in rat hepatocytes. Biochem Pharmacol 39: 1869-1875, 1990.

30. Ashby J, Tinwell H, Lefevre PA and Browne MA: The single cell gel electrophoresis assay for induced DNA damage (comet assay): measurement of tail length and moment. Mutagenesis 10: 85-90, 1995. 
31. Tice RR, Andrews PW and Singh NP: The single cell gel assay: a sensitive technique for evaluating intercellular differences in DNA damage and repair. Basic Life Sci 53: 291-301, 1990.

32. Olive PL, Banath JP and Durand RE: Detection of etoposide resistance by measuring DNA damage in individual chinese hamster cells. J Natl Cancer Inst 82: 779-783, 1990.

33. Jiang MR, Li YC, Yang Y and Wu JR: c-Myc degradation induced by DNA damage results in apoptosis of cho cells. Oncogene 22 3252-3259, 2003.

34. Marnett LJ: Oxyradicals and DNA damage. Carcinogenesis 21: 361-370, 2000.

35. Epe B: Role of endogenous oxidative DNA damage in carcinogenesis: what can we learn from repair-deficient mice? Biol Chem 383: 467-475, 2002.

36. Cimprich KA and Cortez D: ATR: an essential regulator of genome integrity. Nat Rev Mol Cell Biol 9: 616-627, 2008.

37. Lou Z, Minter-Dykhouse K, Wu X and Chen J: MDC1 is coupled to activated $\mathrm{CHK} 2$ in mammalian DNA damage response pathways. Nature 421: 957-961, 2003.
38. Liu Y and Kulesz-Martin M: p53 protein at the hub of cellular DNA damage response pathways through sequence-specific and non-sequence-specific DNA binding. Carcinogenesis 22: 851-860, 2001

39. Shiotani B and Zou L: Single-stranded DNA orchestrates an ATM-to-ATR switch at DNA breaks. Mol Cell 33: 547-558, 2009.

40. Choi JH, Sancar A and Lindsey-Boltz LA: The human ATRmediated DNA damage checkpoint in a reconstituted system. Methods 48: 3-7, 2009.

41. Venkitaraman AR: Cancer susceptibility and the functions of BRCA1 and BRCA2. Cell 108: 171-182, 2002.

42. Mi J, Dziegielewski J, Bolesta E, Brautigan DL and Larner JM: Activation of DNA-PK by ionizing radiation is mediated by protein phosphatase 6. PLoS One 4: e4395, 2009.

43. Jesien-Lewandowicz E, Jesionek-Kupnicka D, Zawlik I, et al: High incidence of MGMT promoter methylation in primary glioblastomas without correlation with TP53 gene mutations. Cancer Genet Cytogenet 188: 77-82, 2009. 